\title{
MANDAMUS TO REVIEW JUDGMENTS OF ACQUITTAL IN FEDERAL COURTS*
}

The Second Circuit recently granted a writ of mandamus vacating a district court's judgment of acquittal in a criminal case, ${ }^{1}$ and ordering retrial of the acquitted defendants. ${ }^{2}$ This case-In re United States-in addition to raising serious questions of double jeopardy, necessitates an inquiry into the proper scope of appellate jurisdiction. At trial, the government's first two witnesses were extensively questioned by the trial judge, who corrected their grammar, ridiculed their choice of words and cautioned them against perjury. ${ }^{3}$ The second witness, after conferring with one of the Assistant United States Attorneys during an overnight recess, changed his testimony. Because the judge considered such conduct by the prosecutor a serious infringement of the defendant's civil rights, and because he regarded the testimony of the two witnesses produced by the Government as wholly unworthy of belief, a formal judgment of acquittal was entered prior to the close of the Government's case."

The Government applied for a writ of mandamus to compel the district court to set aside its judgment and resume the trial. The Court of Appeals found that "the Assistant United States Attorney was not guilty of misconduct or impropriety," and also that acquittal had been granted on "evidence, showing no defense and long before the government had had an opportunity to show whether or not it had a case." The appellate court characterized the trial judge's entry of acquittal as a "usurpation of power" on the ground that the action taken below amounted to a refusal to enforce the criminal law."

*In re United States, 286 F.2d 556 (1st Cir. 1961).

1. In re United States, 286 F.2d 556 (1st Cir. 1961), cert. granted sub nom. Fong Foo v. United States, and Standard Coil Prods. Co. v. United States, 366 U.S. 959 (1961).

2. The defendants, two individuals and a corporation, were indicted for alleged conspiracy and fraud in connection with the production and testing of electronic equipment for the federal government. 286 F.2d at 558.

3. Id. at 558. Seven days of testimony were heard. During the fifth day the trial judge in a conference at the bench recommended that the prosecution nolle prosse its case, since even if in the unlikely event the jury were to return a verdict of conviction, he would almost inevitably have to set it aside. Record, pp. 370-84. The government insisted that the testimony so far heard was not material to its case, and that witnesses to follow would establish the fraud charged in the case. Ibid.

4. See 286 F.2d at 560 .

5. Id. at 562. As the Court of Appeals correctly noted, ibid., there appears to be no "elementary rule" which forbids conversations between a prosecutor and his witness during a recess. Quite the contrary, where the purpose of such conversations was to elicit the truth on further testimony, such conduct has been commended by appellate courts. See Frazer v. United States, 233 F.2d 1, 2 (9th Cir. 1956).

6. 286 F.2d at 563 .

7. Id. at 562,564 . 
Since criminal acquittals in federal courts are not directly appealable, ${ }^{8}$ error by the trial court in exercising its powers would not, absent the "usurpation" characterization, have been reviewable. 9 Yet the appellate court specifically refused to hold that a judge may not, under some circumstances, properly enter a judgment of acquittal as soon as he becomes convinced that the government has "no case." 10 Nor did it hold that misconduct of the prosecutorone of the grounds for the trial court's decision-could not provide a suffcient ground for entry of such a judgment. ${ }^{11}$ The appellate court concluded only that the circumstances involved in the case before it did not justify entry of a judgment of acquittal. ${ }^{12}$ Whatever the validity of this finding, however, "usurpation of power" in a strictly logical sense implies the exercise of a power not possessed; and not the improper use of discretion. ${ }^{13}$ Thus, so long as a judgment of acquittal prior to the close of the prosecution's case could properly have been entered under some circumstances by a trial judge convinced that the government's case must fail, it could be argued that the trial court in the instant case must have possessed the power to act as it did.

The trial court's action, however, might validly be considered "usurpation" if Rule $29 \mathrm{a}$ of the Federal Rules of Criminal Procedure ${ }^{14}$ could be construed to require a full hearing of the prosecution's case before entry of a judgment of acquittal. Such a requirement would constitute a so-called ministerial duty, and failure to comply with such a duty could then be considered equivalent to the exercise of an unconferred power. ${ }^{15}$ But judgments of acquittal have been

8. See Carroll v. United States, 354 U.S. 394 (1957).

9. As the Court of Appeals conceded: "The writ is not available "to correct a mere error in the exercise of conceded judicial power.'" 286 F.2d at 562 (quoting from De Beers Consol. Mines, Ltd. v. United States, 325 U.S. 212, 217 (1945)). Traditionally, mandamus does not lie to correct error taken within the legal discretion of the trial judge, but only to confine the inferior court to a lawful exercise of its prescribed jurisdiction or to compel it to exercise its authority when it is its duty to do so. See Roche v. Evaporated Milk Ass'n, 319 U.S. 21, 26 (1943) ; Ex parte United States, 287 U.S. 241 (1932).

10. 286 F.2d at 562 .

11. 286 F.2d at 562 n.5. But see id. at 567 (concurring opinion).

12. Id. at 563 .

13. The majority thought it appreciated this distinction. Id. at 562. But sec the concurring opinion: "I believe the court has been misled by the relative magnitude of the ... error into confusing a difference in degree with a difference in kind." Id. at 566.

14. FED. R. CRIM. P. 29a, 18 U.S.C. Appendix (1958): Motion for AcquittalMotions for a directed verdict are abolished and motions for judgment of acquittal shall be used in their place. The court on motion of a defendant or of its own motion shall order the entry of judgment of acquittal of one or more offenses charged in the indictment or information after the evidence on either side is closed if the evidence is insufficient to sustain a conviction of such offense or offenses.

15. If the law has pointed out how or in what way the discretion shall be exercised, it is obviously not the exercise of the discretion imposed by law to proceed in any other way.

Huidekoper v. Hadley, 177 Fed. 1, 9 (8th Cir. 1910). See also De Beers Consol. Mines, Ltd. v. United States, 325 U.S. 212 (1945); United States Alkali Export Ass'n v. United States, 325 U.S. 196 (1945). 
rendered before the close of the prosecution's case, where the government's opening statement shows that it has no case, ${ }^{16}$ or where the government's own evidence indicates the existence of an iron-clad defense. ${ }^{17}$ Such instances might be reconciled with the Rule on the theory that such an absolute failure of the evidence effectively completes the prosecution's case and renders further evidence irrelevant. But this rationale would be equally applicable to the instant case. Once the trial court in In re United States was convinced that the prosecution must fail, further evidence became irrelevant and the requirement of the Rule was therefore satisfied.

It is doubtful, moreover, that Rule $29 \mathrm{a}$ should be construed so as to place any limitations upon the trial court's power to enter a judgment of acquittal. The rule contains no positive prohibition to that effect. Nor did it change the common law, ${ }^{18}$ which, by making no allowance for appellate review of acquittals, placed no enforceable limitations upon the judge's power to enter a judgment of acquittal. ${ }^{19}$ Furthermore, there is little functional justification for reviewing a trial court's action in entering judgment as soon as it becomes apparent that the case must fail, since a judgment of acquittal at the close of the evidence would admittedly not be reviewable, even where the trial court offered no reason for its action. ${ }^{20}$ And this argument seems especially convincing if reasons more subjective than quantitative insufficiency of the evidence-such as prosecutorial misconduct ${ }^{21}$-may justify a judgment of acquittal.

16. See, c.g., Illinois Power \& Light Corp. v. Hurley, 49 F.2d 681, 684 (8th Cir. 1931); United States v. Dietrich, 126 Fed. 676 (C.C.D. Neb. 1904).

17. See, e.g., United States v. Maryland Coop. Milk Producers, Inc., 145 F. Supp. 151, 152 (D.D.C. 1956) ; McGuire v. United States, 152 F.2d 577, 580 (8th Cir. 1945).

18. The purpose of changing the name of a motion for a directed verdict to a motion for a judgment of acquittal is to make the nomenclature accord with the realities. The change of nomenclature, however, does not modify the nature of the motion or enlarge the scope of matters that may be considered.

Notes of Advisory Committee on Rules, Note to Rule 29a, 18 U.S.C. Appendix (1958).

19. Ex parte Gordon, 66 U.S. (1 Black) 503 (1862). Since at common law, there was no appellate jurisdiction from a judgment, it would appear that a trial judge having jurisdiction to try the cause, could acquit whenever and for whatever reason (absent fraud) he saw fit, however erroneous his determination. See United States v. Weissman, 266 U.S. 377,379 (1924) (presence of a jury and prisoners is all that is necessary for jurisdiction to vest in the trial court, and the direction of verdict, however erroneous, held to be unreviewable).

20. Rule 29 a does not require that a motion for judgment of acquittal be submitted in writing, nor that a trial judge give reasons for granting such a motion. Conceivably, an appellate court could, by mandamus, require a trial court to state reasons for its action. Cf. United States v. Carter, 231 U.S. 492, 494 (1913). But mandamus has been used in such cases only in order to determine whether a trial court's dismissal of an action qualified for review under the Criminal Appeals Act. See note 44 infra. Since an acquittal without recharacterization, see note 33 infra and accompanying text, is not reviewable under prevailing jurisdictional statutes, however, compelling the trial court to give reasons for its action in such a case would presumably not be in aid of the court's appellate jurisdiction. See notes $39-49$ infra and accompanying text.

21. Evidence might also be legally insufficient because of quality as well as quantity. 
Appellate review of a judgment of acquittal would in any event have little utility if a plea of former jeopardy were available to the defendant at a second trial for the same offense. ${ }^{22}$ But the Court of Appeals in In re United States held that the trial judge's lack of power vitiated the basis for any such claim of former jeopardy. ${ }^{23}$ Until recently, the mere fact that the original trial had been terminated and the original jury discharged without the consent of the defendant or the existence of some compelling physical necessity, would, even if the acquittal could be considered a nullity, have been sufficient to raise problems of double jeopardy. ${ }^{24}$ In the recent case of Gori $v$. United States, ${ }^{25}$ however, the Supreme Court held that discharge of a jury by the trial judge in order to protect defendant's rights, even absent consent of the defendant or a demonstration of any compelling necessity, does not necessarily operate to bar another trial. In the instant case, as in Gori, defendants did not move for a new trial, and no compelling necessity existed for terminating the original proceedings. The grounds for termination of both proceedings, moreover, were alleged flaws in the presentation of the government's case, which were said by the trial courts to justify action to protect the defendant's rights. ${ }^{23}$ As a result, since the action taken in Gori was not considered the type of abuse of discretion which would bar a new trial (for example, employing judicial authority to rescue the prosecution from a case which is going bad$1 y)^{27}$ but rather was adjudged a valid exercise of the discretion given to a trial judge to assure the fair conduct of trial proceedings, ${ }^{28}$ the discharge of

Incredible testimony of government witnesses could so taint its case as to require a trial court to set aside a verdict of conviction entered on the basis of such evidence. $C f$. Ex parte United States, 101 F.2d 870, 878 (7th Cir. 1939).

22. Cf. Green v. United States, 355 U.S. 184, 188 (1957); Regina v. Miles, 24 Q.B. Div. 423, 431 (1890). See also Mayers \& Yarbrough, Bis Vexari: New Trials and Stccessive Prosecutions, 74 Harv. L. Rev. 1 (1960); Comment, 65 YALE L.J. 339 (1956); Note, 24 MINN. L. REV. 522 (1940).

23. 286 F.2d at 565 .

24. Jeopardy was said to attach, if at all, "when a person has been placed on trial before a court of competent jurisdiction under a valid indictment, has been arraigned and has pleaded, and a proper jury impaneled and sworn to hear the evidence." Note, 24 Mris. L. REv. 522, 527 (1940) (collecting cases). Courts early recognized so-called exceptions to the rule, however, holding that if the jury was discharged for some compelling necessity, United States v. Perez, 22 U.S. (9 Wheat.) 579 (1824) (hung jury), or if the defendant himself moved for, or consented to a mistrial, Blair v. White, 24 F.2d 323 (8th Cir. 1928), the defendant could again be put upon trial. While the Perez rule and its extensions, see Comment, 36 N.Y.U.L. Rev. 730 (1961) ; 47 VA. I. Rev. 122 (1961), have modified the defendant's right to a verdict from the original jury, the right has not been extinguished. Entry of a nolle prosequi after jeopardy has attached and without consent of the accused, for example, will bar another prosecution, Clawans v. Rives, 104 F.2d 240 (D.C. Cir. 1939); United States v. Farring, 25 Fed. Cas. 1052 (No. 15075) (D.C. Cir. 1834).

25. 367 U.S. 364 (1961), affirming 282 F.2d 43 (2d Cir. 1960).

26. See In re United States, 286 F.2d 556, 559, 560 (1st Cir. 1961) ; Gori v. United States, 367 U.S. 364, 368 (1961).

27. 367 U.S. at 369.

28. Both the Supreme Court and the Court of Appeals in Gori were influenced in their decisions to allow retrial by a reluctance to interfere with the district court's responsibility 
the jury by the trial court in In re United States need not be considered such an abuse of discretion as would bar a new trial. ${ }^{29}$

The Gori holding gave to trial judges the power to declare a mistrial in situations where continuation of the proceedings would prejudice defendant's rights, but where a new trial would not be oppressive. ${ }^{30}$ The willingness of the Supreme Court to disregard double jeopardy protections in such situations suggests an attempt to provide more flexible means for controlling the conduct of trial proceedings than that afforded by rigidly defined constitutional prohibitions. Broadening the scope of appellate review would, of course, also serve such ends. Nevertheless the expanded powers given to the trial judge by the Gori decision rest on the explicit assumption that the trial judge is in a better position than an appellate court, which views the proceedings through a cold record, to determine whether defendant's rights have been violated. Such an assumption could also imply that the trial judge is in the best position to determine whether the violations are such as would render retrial oppressive, and therefore make an acquittal rather than a mistrial appropriate. Considered in this light, the Gori rationale would appear to support the action of the trial judge in In re United States.

Whether or not the trial court's discharge of the jury is considered an abuse of discretion, double jeopardy objections might nevertheless prevail if the formal judgment of acquittal rendered by the trial court is ultimately regarded by the Supreme Court as final for double jeopardy purposes. ${ }^{31}$ The constitutional validity of appellate review of acquittals and subsequent retrial upon a finding of error has not yet been determined, but it has been authoritatively suggested that the legislative authorization of appellate review of acquittals would not violate the Constitution, on the ground that the fifth amendment provision against double jeopardy bars retrial only in cases involving an errorfree acquittal. ${ }^{32}$ As a result, if the Court of Appeals could properly review the trial court's action by means of mandamus and recharacterize the judgment as something other than an acquittal, the fact that a judgment, formally denominated as acquittal, was entered by the trial judge need not be con-

for the conduct of a criminal trial and a belief that the trial judge should play an active part in protecting the rights of the parties. See 282 F.2d at $47 ; 367$ U.S. at 369, 370. Since the mistrial clearly was declared in the interests of the defendant, the Supreme Court was unwilling to hold that its necessary result was to bar retrial, reasoning that a trial judge, aware that a mistrial may bar retrial, will then be less likely to mistrial to protect defendant's rights. 367 U.S. at 370.

29. But cf. United States v. Whitlow, 110 F. Supp. 871 (D.D.C. 1953).

30. See note 28 supra.

31. See, e.g., Green v. United States, 355 U.S. 184, 188 (1957) ; United States v. Ball, 163 U.S. 662, 667 (1896). Even the dissenters in Green emphasized that the main object of the constitutional protection against double jeopardy was to prohibit new trial after acquittal. See, e.g., 355 U.S. at 202; see also Kepner v. United States, 195 U.S. 100 (1904).

32. See United States v. Sanges, 144 U.S. 310, 318 (1892) ; Kepner v. United States, supra note 31, at 135 (Holmes, J., dissenting). Cf. Palko v. Connecticut, 302 U.S. 319 (1937) (fourteenth amendment due process clause). 
sidered, in constitutional terms, as conclusive for double jeopardy purposes. Moreover, appellate courts, without considering possible double jeopardy issues, have, in order to effectuate the congressional policy of protecting the government's statutory right to limited review, reversed judgments formally denominated as acquittals after recharacterizing such judgments as orders reviewable under the Criminal Appeals Act. ${ }^{33}$ No precedent exists, however, for recharacterizing a judgment of acquittal, where the judgment could in no circumstances be construed as a possible subject for appellate review under the Criminal Appeals Act. ${ }^{34}$ Consequently, even if the Court of Appeals' action in ordering a new trial does not constitute double jeopardy, its recharacterization of the judgment of acquittal must be evaluated in terms of the congressional policy governing appellate review of federal criminal cases, especially in light of repeated judicial insistence on a clear statutory mandate as a prerequisite to the exercise of appellate jurisdiction in criminal cases. ${ }^{35}$

In some areas of the law, however, situations in which the language of "jurisdiction" and "power" is invoked are not classifiable in terms of the rigid confines of logical constructs. Thus, in administrative law cases, courts have often denominated certain questions as jurisdictional and characterized otherwise unreviewable actions taken by administrators as "usurpations," in order to introduce a measure of judicial supervision over the activities of administrative agencies. ${ }^{36}$ Attempts to bar judicial review of administrative actions completely, however, involve considerations such as the extent to which the due process clause requires that certain governmental decisions affecting individual rights be subject to control by the judiciary. ${ }^{37}$ As a result, func-

33. Thus, though the government cannot appeal directed verdicts of acquittal, when a district court, after a conviction, granted a motion to acquit the defendant on the ground that the indictment did not state an offense under the criminal statutes, the appellate court treated the motion as one in arrest of conviction and certified it to the Supreme Court. United States v. Waters, 175 F.2d 340 (D.C. Cir.), appeal dismissed, 335 U.S. 869 (1948). See also United States v. Apex Distrib. Co., 270 F.2d 747 (9th Cir. 1959). But cf. Carroll v. United States, 354 U.S. 394, 406 (1957). See also notes $44-49$ infra and accompanying text for discussion of the Criminal Appeals Act.

34. See Carroll v. United States, supra note 33; cf. United States v. Janitz, 161 F.2d 19 (3d Cir. 1947). See also United States v. Weissman, 266 U.S. 377 (1924).

35. [I]n the federal jurisprudence, at least, appeals by the Government in criminal cases are something unusual, exceptional, not favored. The history shows resistance of the Court to the opening of an appellate route for the Government until it was plainly provided by the Congress, and after that a close restriction of its uses to those authorized by the statute.

Carroll v. United States, 354 U.S. 394, 400 (1957). See also United States v. Heath, 260 F.2d 623 (9th Cir. 1958).

36. See, e.g., Cotonificio Bustese, S.A. v. Morgenthau, 121 F.2d 884 (D.C. Cir. 1941); cf. Estep v. United States, 327 U.S. 114, 122-23 (1946) ; Harmon v. Brucker, 355 U.S. 579 (1958). See also Jaffe, Judicial Revievo: Constitutional and Jurisdictional Fact, 70 Harv. L. REv. 953, 963, 966 (1957); Jaffe, Judicial Review: Questions of Fact, 69 HARv. L. Rev. 1020, 1045 (1956) ; Note, 25 Iowa L. Rev. 638, 641 (1940).

37. See, e.g., Ohio Valley Water Co. v. Ben Avon Borough, 253 U.S. 287 (1920); Ng Fung Ho v. White, 259 U.S. 276 (1922) ; Crowell v. Benson, 285 U.S. 22, 57 (1932); 
tional inroads by appellate courts on jurisdictional provisions barring review seem peculiarly appropriate when the question is one of reviewing such administrative action.

Recent developments in criminal procedure have vastly expanded the significance of appellate review of trial court supervision over criminal proceedings. Supreme Court decisions giving content to constitutional and statutory safeguards such as the right to counsel, to jury, and to fair and impartial trial; freedom from self-incrimination, wiretapping and illegal searches and seizures, have greatly increased the possibility that the trial proceeding in any given case may be found fatally defective because rulings by the trial judge failed to protect defendants' liberties.

It could therefore be argued that this insistence by appellate courts that trial judges actively supervise the trial to ensure that certain established minimum standards are maintained, places the trial judge essentially in the role of an "administrator," and thus the more functional approach toward jurisdictional limitations employed in appellate review of administrative agency determinations may be equally applicable to jurisdictional issues raised by the limitations placed upon appellate review of decisions adverse to the government in criminal cases. A legislative recognition that broader appellate review may be necessary to protect the interest of the government may be implied from congressional proposals to grant the government appellate review of suppression orders. ${ }^{38}$ But the Government has no constitutional right to increased protection; and given the vast historical and constitutional differences which separate appellate review in the criminal law from judicial control of the administrative process, it seems especially necessary that attempts to expand the scope of judicial review in criminal cases be preceded by careful inquiry into existing statutory provisions.

The necessity for close adherence by courts to the congressional policies concerning criminal appeals embodied in statutes defining the jurisdiction of appellate courts should be apparent. Federal courts are courts of limited jurisdiction: the limits on jurisdiction represent that distribution of judicial power in our federal system which is deemed optimal by Congress. ${ }^{39}$ Courts, unlike Congress, are not accountable bodies. Yet it is the courts themselves which must determine whether or not they have been given jurisdiction over any particular question. Given judicial lack of accountability, in other words, limitations upon jurisdiction are ultimately self-imposed. And only self-restraint can prevent expansive constructions of jurisdictional statutes, resulting in the seizure of power which Congress did not intend to confer. Disavowal of jurisdictional power, in any given case, may offend an appellate

Mitchell v. United States, 313 U.S. 80 (1941) ; Henderson v. United States, 339 U.S. 816 (1950). See generally Jaffe, supra note 36.

38. See, e.g., H.R. Doc. No. 263, 85th Cong., 1st Sess. (1957) ; H.R. Doc. No. 9364, 84th Cong., 2d Sess. (1956).

39. See Moore, Commentary on the United States Judictal Code $\llbracket 0.03(27)$, at 160 (1949). 
court's sense of substantial justice, because of the possibility that rigid adherence to limits couched in jurisdictional terms may permit errors below to remain unrectified. Nevertheless, the arguments which favor appellate intervention in "appropriate" cases must be balanced against the fact that appellate transgressions of jurisdictional limitations may be no less "usurpations of power" than those actions by trial courts which prompt such unauthorized review.

That congressional policy supports only limited review in criminal cases is apparent from the history of the relevant jurisdictional statutes. ${ }^{40}$ Prior to the Acts of 1889 and 1891,41 no jurisdictional provisions existed allowing appellate review of criminal cases. ${ }^{42}$ These Acts established jurisdictional provisions allowing appeal and writ of error by defendants, but the Acts were construed not to allow review by the government.43 The enactment of the Criminal Appeals Act ${ }^{44}$ in 1907 permitted the United States for the first time to appeal an adverse decision in a criminal case, but such appeals were limited to rulings sustaining a demurrer to the indictment, granting a motion in arrest of judgment based upon the invalidity or construction of the statute upon which the indictment was founded, or allowing a plea in bar. ${ }^{45}$ Furthermore, despite contentions by proponents of the statute that the jurisdictional provisions dealt only with preliminary proceedings on questions of law, ${ }^{40}$ resistance on the floor of Congress was so great ${ }^{47}$ that an additional cautionary provision was added, explicitly barring review in any case where a "verdict in favor of the defendant" 48 had been entered. Subsequent amendments have not substantively modified this position. ${ }^{49}$

40. See generally Friedenthal, Governnent Appeals in Federal Criminal Cases, 12 Stan. L. Rev. 71 (1959).

41. Act of February 6, 1889, ch. 113, 25 Stat. 655 (1889) ; Judiciary Act of March 3, 1891 , ch. 517, 26 Stat. 826 (1891).

42. However, where the judgment of conviction was not merely erroneous, but was void or illegal because of want of jurisdiction, fraud, or non-identity, the convicted defendant could always gain relief, even in the absence of jurisdictional provisions for appeal or writ of error, by application for the writ of habeas corpus. See, e.g., Ex parte Siebold, 100 U.S. 371 (1879) ; Ex parte Yarbrough, 110 U.S. 651 (1884).

43. United States v. Sanges, 144 U.S. 310 (1892). See also Carroll v. United States, 354 U.S. 394, 400-03 (1957).

44. Act of March 2, 1907, ch. 2564, 34 Stat. 1246 (1907) (repealed by Act of June 25, 1948, ch. 6451, \& 21, 62 Stat. 862 (1948).

45. Even if the dismissal is clearly based on a plea in bar, however, review under the Act is barred if the defendant has been put in jeopardy. See Friedenthal, supra note 40, at 71,72 n.6.

46. See H.R. Rep. No. 2119, 59th Cong., 1st Sess. 1, 3 (1906) ; 41 Cong. Rec. 2193, 2752, 2762 (1907). See also Carroll v. United States, 354 U.S. 394, 402 (1957).

47. See, e.g., 41 Cong. Rec. 2192-94, 2819 (1907).

48. See Criminal Appeals Act, Act of March 2, 1907, ch. 2564, 34 Stat. 1246 (1907) (repealed by Act of June 25, 1948, ch. 645, $\$ 21,62$ Stat. 862 (1948)), now 18 U.S.C. $\S 3731$ (1958). See also Carroll v. United States, 354 U.S. 394, 401 n.10 (1957) and congressional materials cited therein.

49. The scope of appellate review under the Criminal Appeals Act remained unchanged for 35 years. In 1942, Congress added a provision allowing review by the courts of appeals 
The court in the instant case 50 found its authority for review, not in a statute governing criminal appeals, but in the All Writs statute, which provides that "the Supreme Court, and all courts established by Act of Congress, may issue all writs necessary or appropriate in aid of their respective jurisdictions and agreeable to the usages and principles of law."51 Under the provisions of this statute, the writ of mandamus is authorized, not only where issuance is required in aid of a jurisdiction already obtained, but also where a case is potentially within the appellate jurisdiction of the higher court, and such jurisdiction might otherwise be defeated or impaired by unauthorized action on the part of the court below. ${ }^{52}$ Ex parte United States ${ }^{53}$ was cited by the Court of Appeals in the present case as authority for its power to issue the writ. ${ }^{54}$ In that case mandamus issued to compel the grant of a bench warrant, although the trial judge's previous refusal was not directly reviewable. The arbitrary or erroneous refusal of a court to act, thereby thwarting the entry of an appealable final judgment, is one of the traditional grounds on which review by means of mandamus has been based in cases where appeal is otherwise unavailable. ${ }^{55}$ Proceeding by analogy, the Court of Appeals in the present case reasoned that if mandamus is available from other unappealable final orders of a trial court, it must be available as well, from an otherwise unappealable judgment of acquittal, in situations where that judgment prevents an adequate exposition of the issues. ${ }^{56}$ In Ex parte United States, ${ }^{57}$ however, while there was no provision for direct appeal from the judge's order, Congress had expressed no policy against review of orders preventing

in cases in which an indictment or information was dismissed on the ground that it was defective as a pleading, or was unlawfully obtained, and increasing the appellate jurisdiction of the Supreme Court by including cases involving informations as well as indictments. Act of May 9, 1942, ch. 295, 56 Stat. 271 (1942). Subsequent to the adoption of Rule 12 of the Federal Rules of Criminal Procedure which simplified the rules of pleading, the Act was again amended to conform to the new nomenclature. Act of June 25, 1948, ch. $645, \S 21,62$ Stat. 862 (1948), 18 U.S.C. $\$ 3731$ (1958). However, no substantive changes were effected by the amendment. See Friedenthal, supra note 40, at $72 \mathrm{n.7}$; United States v. Pack, 247 F.2d 168 (3d Cir. 1957). Since 1948, the only enlargement of appellate jurisdiction in federal criminal cases has been a provision allowing review of pretrial suppression orders in narcotics cases. 18 U.S.C. $\$ 1404$ (1958). See Friedenthal, supra note 40 , at 96 .

50. See 286 F.2d at 563,564 .

51. 28 U.S.C. $\$ 1651$ (1958).

52. See McClellan v. Carland, 217 U.S. 268 (1910); La Buy v. Howes Leather Co., 352 U.S. 249 (1957); Ex parte Peru, 318 U.S. 578 (1943); Wolfson, Extraordinary Writs In the Supreme Court Since Ex Parte Pern, 51 Colun. L. Rev. 977 (1951); 6 Moore, Federal Practice $\int 54.10$ (2), at 65 (2d ed. 1953).

53. 287 U.S. 241 (1932).

54. 286 F.2d at 563,564 .

55. See, e.g., Ex parte United States, 242 U.S. 27 (1916); New York Life \& Fire Ins. Co. v. Wilson, 33 U.S. (8 Pet.) 291 (1834). See also 6 Moore, FEderaL Pracrice If $54.10(6)$, at 108 (2d ed. 1953).

56. 286 F.2d at 564 .

57. 287 U.S. 241 (1932). See also Frankel v. Woodrough, 7 F.2d 796 (8th Cir. 1925). 
cases from going to trial; in In re United States, direct review of the trial court's action was unavailable precisely because of an explicit and long standing congressional policy denying such review. Thus, whereas in Ex parte United States, the trial judge's decision prevented a final judgment which might otherwise have been reviewable, in In re United States the judge's decision was itself the final judgment which Congress sought to make unreviewable.

The Court of Appeals in In re United States also referred to the case of La Buy v. Howes Leather Co. $;^{88} \mathrm{La}$ Buy, however, is distinguishable from the instant case on the same grounds as Ex parte United States. In La Buy, there was potential jurisdiction which the writ might aid, ${ }^{68}$ and the policy against piece-meal appeals ${ }^{60}$ and the final judgment rule ${ }^{61}$ was held not to preclude the issuance of the writ in exceptional circumstances. ${ }^{62}$ Justice Brennan, dissenting, contended that the majority was granting the Court of Appeals a general supervisory power over lower courts, independent of jurisdictional statutes. ${ }^{63}$ Assuming that the Court of Appeals has such a general supervisory power, its existence might justify the writ's issuance in the instant case in the interests of proper judicial administration. But in $L a B u y$, the writ was used to review an interlocutory order. The argument for permitting use of extraordinary writs to review interlocutory orders, ordinarily nonappealable, is that Congress did not intend the applicable provisions to function as an absolute bar to review under all circumstances. Rather, the policy underlying the All Writs Statute was precisely to provide for the use of extraordinary writs where subsequent appeal would be inadequate, in order to maintain a necessary flexibility without enlarging the categories of interlocutory appeals available as of right. ${ }^{64}$ But where there is a clear statutory policy against review of a particular order, as in the case of acquittals, courts traditionally have refused to issue the writ. ${ }^{65}$

As the Court of Appeals suggested in Gori, the public interest is often better served by assuring the proper administration of the criminal law and con-

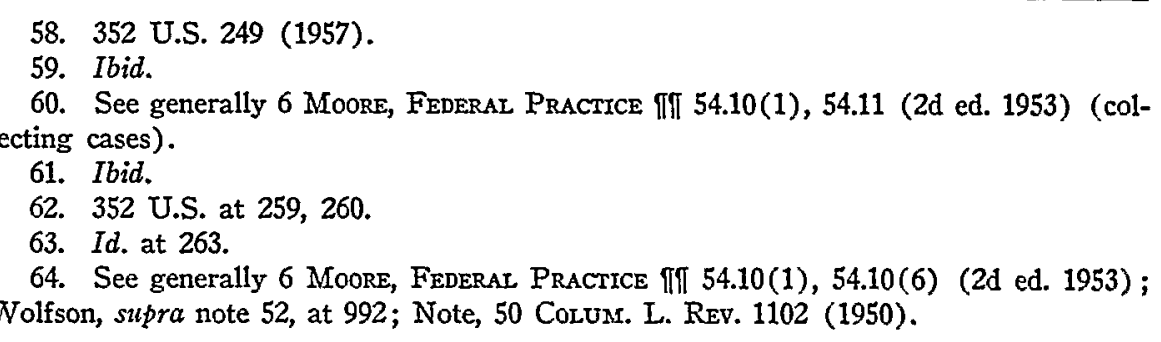

65. See, e.g., Ex parte McCardle, 74 U.S. (7 Wall.) 506 (1864); United States v. Rice, 327 U.S. 742 (1946); In re Pennsylvania Co., 137 U.S. 451 (1890); Kloeb v. Armour \& Co., 311 U.S. 199 (1940) ; Employers Reins. Corp. v. Bryant, 299 U.S. 374 (1937) ; Mutual Life Ins. Co. v. Holly, 135 F.2d 675 (7th Cir. 1943); Lewis v. United Gas Pipe Co., 194 F.2d 1005 (5th Cir.), cert. denied, 343 U.S. 974 (1952) ; Ex parte Farrell, 189 F.2d 540 (1st Cir. 1951). See also 6 Moore, Federal. Practice If $54.10(2)$ n.41, 54.10(3) n.55, 54.10(4) n.17 (2d ed. 1953) and accompanying texts. 
viction of the guilty than by shielding defendants from a new trial when they have benefited from an error by the court below. ${ }^{66}$ And in effectuating such a policy, courts have tended to limit the scope of the doctrine of double jeopardy. A similar argument could be made, certainly; for allowing appeals by the state from acquittals. In cases such as Gori where the issue is one of double jeopardy alone, courts are recognized as the agencies charged with the interpretation of the Constitution and the determination of the limits of constitutional doctrines. But in cases such as In re United States, where the issue of double jeopardy is perhaps subordinate to problems concerning the permissible scope of appellate review, ${ }^{67}$ it is the legislature, not the courts, which has traditionally been recognized as the proper agency for valuing the relevant determinations. If the decision in In re United States is to be justified on the basis of the policies which dictated the result in Gori, the importance of these policies must first be balanced against the values embodied in judicial adherence to congressional determinations of federal appellate jurisdiction. ${ }^{b s}$

66. 282 F.2d at 48.

67. Quare whether the issues of appellate jurisdiction and double jeopardy would be the same if the government, instead of seeking mandamus, had simply retried the defendants and obtained a conviction in the second trial, which was affirmed by the Court of Appeals over double jeopardy objections by the convicted defendants?

68. See MOORE, silpra note 39 and accompanying text. 